\title{
A New Species of the Family Halichondriidae (Demospongiae: Halichondrida) from Jeju-do Island, Korea
}

\author{
Hye Ri Kim and Chung Ja Sim* \\ Department of biological Sicences, College of Life Sciences and Nano Technology, \\ Hannam University, Daejeon 305-811, Korea
}

\begin{abstract}
A new species of the genus Halichondria (Eumastia) maraensis n. sp. (Demospongiae: Halichondrida: Halichondriidae) was collected from West Marado Island, Daejeong-eup, Seogwipo-si, Jeju-do Island, Korea during the period of Dec. 2006 to Feb. 2007 by a fishing net (60-80 m in depth). Halichondria (E.) maraensis n. sp. is similar to $H$. (E.) sitiens (Schmidt, 1870) in the type of the spicules. However they differ in spicules size and conical fistules at the surface. Oxeas of the new species are smaller and thicker than those of $H$. (E.) sitiens. Surface conules of the new species is not transparent, and has no oscules at the terminal short conules but $H$. (E.) sitiens has hollow papillae and terminal oscules.
\end{abstract}

Key words: Halichondria (Eumastia), new species, sponge, Korea

\section{INTRODUCTION}

The family Halichondriidae are widely distributed and live mainly in shallow coastal waters but a few species have also reported from depth $500 \mathrm{~m}$. The major morphological characters distinguishing this group from related sponges are the thoroughly confused arrangement of the choanosomal megascleres (oxeas, styles) usually coupled with differentiated ectosomal skeleton. It consists of 11 genera, Axinyssa, Amorphinopsis, Ciocalapata, Ciocalypta, Epipolasis, Hymeniacidoan, Halichondria, Laminospongia, Spongosorites, Topsentia and Vosmaeria. Among them, the genus Halichondria has a tangential ectosomal skeleton carried by subectosomal spicule tracts, separated by subdermal spaces. Megascleres are exclusively oxeas or derivates in a wide size range (Hooper and van Soest, 2002). About 110 species are distributed worldwide (Hooper and van Soest, 2002). Nine species of Halichondria have been reported from Korea waters (Kim et al., 1968; Rho and Lee, 1976; Kang and Sim, 2008a, b; Jeon and Sim, 2009). The genus Halichondria has two subgenera. The subgenus Eumastia with the short papillae is newly added in the Korean sponge fauna.

The materials used in this study were collected from West Marado Island, Daejeong-eup, Seogwipo-si, Jeju-do Island, Korea on 15 Dec. 2006 and 6 Feb. 2007, by a fishing net

*To whom correspondence should be addressed

Tel: 82-42-629-8755, Fax: 82-42-629-8751

E-mail: cjsim@hnu.kr
(60-80 $\mathrm{m}$ depth). The specimens collected followed the methods of Kang and Sim (2008b) and Rützler (1978). The specimens examined were deposited in the National History Museum, Hannam University (HUNHM), Daejeon, Korea.

\section{SYSTEMATIC ACCOUNTS}

Phylum Porifera Grant, 1836

Class Demospongiae Sollas, 1885

Order Halichondrida Gray, 1867

Family Halichondriidae Gray, 1867

Genus Halichondria Fleming, 1828

Subgenus Eumastia Schmidt, 1870

${ }^{1} *$ Halichondria (Eumastia) maraensis n. sp. (Fig. 1)

Table 1. The comparison of characters between $H$. (E.) maraensis n. sp. and $H$. (E.) sitiens

\begin{tabular}{|c|c|c|}
\hline Characters & $\begin{array}{c}\text { H. (E.) maraensis } \\
\text { n. sp. }\end{array}$ & $\begin{array}{l}\text { H. (E.) sitiens } \\
\text { (Schmidt, 1879) }\end{array}$ \\
\hline Growth form & Massive-upright & Semi-globular cushion \\
\hline Colour & Yellow & Yellow \\
\hline Surface & $\begin{array}{l}\text { Papillae solid, } \\
\text { no terminal oscules }\end{array}$ & $\begin{array}{l}\text { Papillae hollow, } \\
\text { terminal oscules }\end{array}$ \\
\hline $\begin{array}{l}\text { Spicules } \\
\qquad(\mu \mathrm{m})\end{array}$ & $\begin{array}{c}140-260 \times 5-9 \\
630-1,075 \times 8-35\end{array}$ & $360-1,020 \times 7-20$ \\
\hline
\end{tabular}

$1 *$ 마라해변해면 (신칭) 

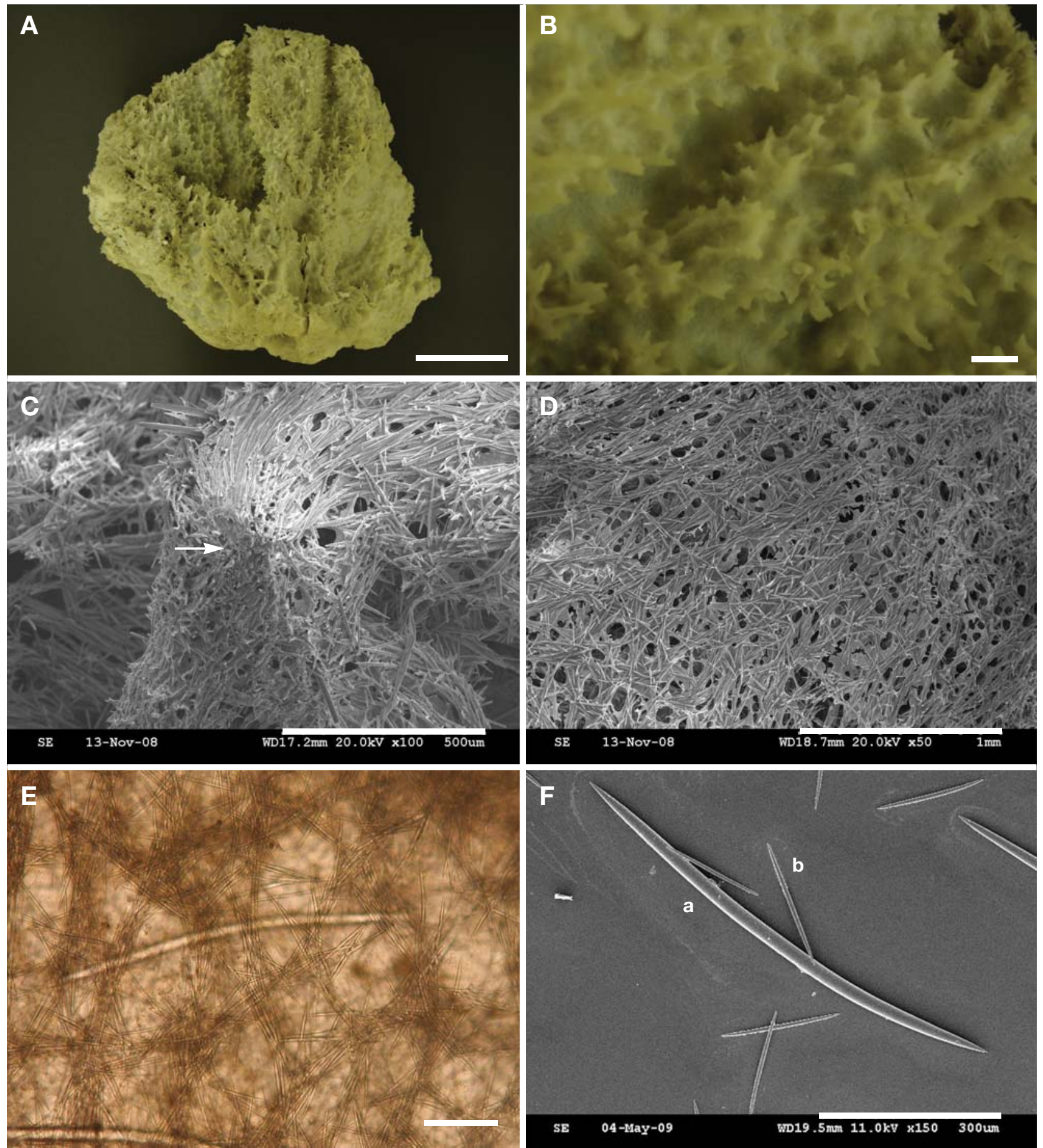

Fig. 1. Halichondria (Eumastia) maraensis n. sp. A, entire animal; B, conules; C, top of the conules (arrow); D-E, ectosomal skeleton; F, oxea (a, large oxea; b, small oxea). Scale bars=3 cm (A), $0.5 \mathrm{~cm}(B), 500 \mu \mathrm{m}(C), 1 \mathrm{~mm}(\mathrm{D}), 200 \mu \mathrm{m}(\mathrm{E}), 300 \mu \mathrm{m}(\mathrm{F})$.

Material examined. Holotype (Por. 100), Paratyle (Por. 1001), West Marado Island, Daejeong-eup, Seogwipo-si, Jejudo Island, 15 Dec. 2006, by a fishing net (80 m depth). Paratype (100-2), West Marado Island, Daejeong-eup, Seogwipo- si, Jeju-do Island, 6 Feb. 2007, $60 \mathrm{~m}$ depth by a fishing net. Deposited in the HUNHM, Daejeon, Korea.

Description. This new sponge, massive-upright, size up to $14 \mathrm{~cm}$ wide, $15 \mathrm{~cm}$ high, $2-5 \mathrm{~cm}$ thick. Surface covered thin 
membrane with short conical papillae reaching $0.1-0.6 \mathrm{~cm}$ high, solid and close to the end. Surface crust with papillae, easily detachable peeled off. Texture hard. Colour yellow in life which gradually changes to white in alcohol. Ectosomal skeleton, tangential arrangement and intercrossing of small oxeas. Choanosomal skeleton, confused in arrangement of large oxeas. Spicules large and small oxeas, no microsleres. Spicules.

Large oxeas $630-1,075 \times 8-35 \mu \mathrm{m}$ Small oxeas $140-260 \times 5-9 \mu \mathrm{m}$

Etymology. The species is named after the type locality, Marado Island, Korea.

Remark. Halichondria (Eumastia) maraensis n. sp. is similar to $H$. (E.) sitiens (Schmidt, 1870) in the type of the spicules. But they differ in spicule size and conical fistules at surface. Oxea of the new species is smaller and thicker than $H$. (E.) sitiens. Surface conules of the new species is not transparent and no oscules at the terminal short conules but $H$. (E.) sitiens has hollow papillae and terminal oscules at the end (Table 1).

\section{ACKNOWLEDGEMENTS}

This research was supported by a grant from Marine Biotechnology Programme funded by Ministry of Land, Transport and Maritime Affairs of Korean Government.

\section{REFERENCES}

Hooper, J.N.A. and W.M. van Soest, 2002. Systema Porifera. A guide to the classification of sponges. Kluwer Academic/ Plenum Publishers Press, USA, pp. 1-1101.

Jeon, Y.J. and C.J. Sim, 2009. A new record of genus Halichondria (Demospongiae: Halichondrida: Halichondriidae) from Korea. Korean J. Syst. Zool., 25(1): 137-139.

Kang, D.W. and C.J. Sim, 2008a. Two new sponges of the genus Halichondria (Halichongdrida: Halichondriidae) from Korea. Animal Cells and Systems, 12(1): 65-68.

Kang, D.W. and C.J. Sim, 2008b. Two new marine sponges of genus Halichondrida (Halichondrida: Halichondriidae) from Korea. Korean J. Syst. Zool., 24(2): 205-208.

Kim, H.S., B.J. Rho and C.J. Sim, 1968. Marine sponges in South Korea (1). Korean J. Zool., 11(2): 37-48.

Rho, B.J. and K.H. Lee, 1976. A survey of marine sponges of Haeundae and its adjacent water. J. Korean. Res. Inst. Better Liv. Ewha Womans Univ., 17: 93-111.

Rützler, K., 1978. Sponges in coral reefs. In Stoddart, D.R. and R.E. Johannes, eds., Coral Reefs: Research Methods. Monogr. Oceanogr. Neth. UNESCO, 5: 299-313.

Received June 15, 2009 Accepted June 23, 2009 